\title{
Geothermal Gradient and Heat Flow in the Nigeria Sector of the Chad Basin, Nigeria
}

\author{
Mohammed Yerima Kwaya ${ }^{1}$, Ewa Kurowska ${ }^{2}$, Abdullahi Suleiman Arabi ${ }^{3}$ \\ ${ }^{1}$ Department of Geology, Usmanu Danfodiyo University, Sokoto, Nigeria \\ ${ }^{2}$ Department of Fundamental Geology, University of Silesia, Katowice, Poland \\ ${ }^{3}$ Center for Energy Research and Training, Ahmadu Bello University, Zaria, Nigeria \\ Email:saarabi@abu.edu.ng
}

Received 16 April 2013; accepted 22 April 2016; published 26 April 2016

Copyright (C) 2016 by authors and Scientific Research Publishing Inc.

This work is licensed under the Creative Commons Attribution International License (CC BY). http://creativecommons.org/licenses/by/4.0/

(c) (i) Open Access

\begin{abstract}
Information on geothermal gradient and heat flow within the subsurface is critical in the quest for geothermal energy exploration. In a bid to ascertain the thermal potential of Nigeria sector of the Chad Basin for energy generation, subsurface temperature information from 19 oil wells, 24 water boreholes drilled to depths beyond 100 metres and atmospheric temperature from the Chad basin were utilized in calculating geothermal gradient of the area. Selected ditch cuttings from the wells were subjected to thermal conductivity test using Thermal Conductivity Scanner (TCS) at the Polish Geological Institute Laboratory in Warsaw. The terrestrial heat flow was calculated according to the Fourier's law as a simple product of the geothermal gradient and the mean thermal conductivity. Results obtained indicated geothermal gradient range of $2.81^{\circ} \mathrm{C} / 100 \mathrm{~m}$ to $5.88^{\circ} \mathrm{C} / 100$ $\mathrm{m}$ with an average of $3.71^{\circ} \mathrm{C} / 100 \mathrm{~m}$. The thermal conductivity values from the different representative samples range from $0.58 \mathrm{~W} / \mathrm{m}^{*} \mathrm{~K}$ to $4.207 \mathrm{~W} / \mathrm{m}^{*} \mathrm{~K}$ with an average of $1.626 \mathrm{~W} / \mathrm{m}^{*} \mathrm{~K}$. The work presented a heat flow value ranging from $45 \mathrm{~mW} / \mathrm{m}^{2}$ to about $90 \mathrm{~mW} / \mathrm{m}^{2}$ in the Nigerian sector of the Chad Basin.
\end{abstract}

\section{Keywords}

Geothermal Gradient, Heat Flow, Chad Basin, Thermal Conductivity

\section{Introduction}

The origin of the Chad Basin is generally attributed to the Rift system that was developed in the early cretaceous when the African and South American lithospheric plates separated and the Atlantic opened. According to [1] the Cretaceous Rift system of West and Central Africa extends for over $4000 \mathrm{~km}$ from Nigeria northwards into 
Niger and Libya and eastwards through southern Chad into Sudan and Kenya.

Heat is a form of energy and "geothermal energy" - in broad sense-is the heat contained within the Earth that generates geological phenomena on a planetary scale as plate tectonics, tectonic and volcanic activity in the Earth crust. In fact nowadays the term "geothermal energy" is often used to emphasize that part of the Earth's heat that can be recovered and exploited by man [2].

This work involves the utilization of corrected borehole temperature from oil wells, temperature from water wells and thermal analysis of rock samples for evaluation of geothermal potentials of the Chad basin. The analysis of these data helps the deduction of shallow crustal structure and geothermal heat distribution within structure of the area. All this is aimed at ascertaining the existence of useful geothermal gradient and heat distribution in the Nigerian sectors of the Chad Basin which may be favourable for geothermal energy exploration in the region.

\section{Regional Geology}

The Chad Basin belongs to a series of Cretaceous and later rift basin in Central and West Africa (Figure 1). The origin is generally attributed to the Rift systems that develop in the early Cretaceous when the African and South American lithospheric plates separated and the Atlantic opened. According to [1] the Cretaceous Rift system of West and Central Africa extend for over $4000 \mathrm{~km}$ from Nigeria northwards into Niger and Libya and eastwards through southern Chad into Sudan and Kenya. The Chad Basin with an area of about 2,335,000 km² ([3] [4]) occupies a vast area at an altitude of between $200 \mathrm{~m}$ and $500 \mathrm{~m}$ above sea level in Central Africa [5]. The Bornu Basin (Nigerian sector of the Chad Basin) makes up approximately 10 percent of the basin and lies between latitude $11^{\circ} \mathrm{N}$ and $13^{\circ} 45^{\prime} 38^{\prime \prime} \mathrm{N}$ and longitudes $8^{\circ} 21^{\prime} 49^{\prime \prime}$ and $14^{\circ} 40^{\prime} 22^{\prime \prime} \mathrm{E}$ in north-eastern Nigeria [6].

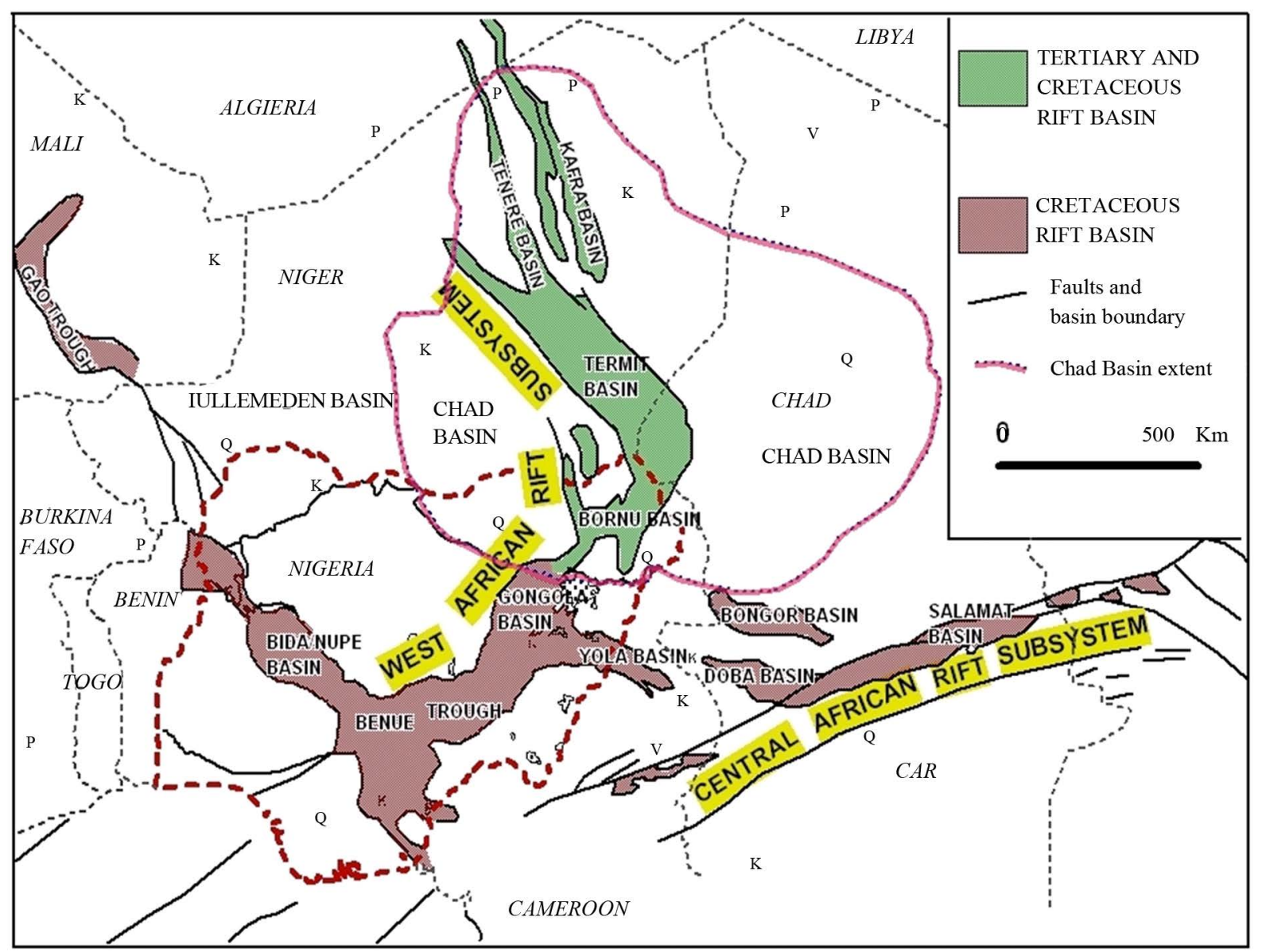

Figure 1. Location of Nigeria and Chad/Bornu Basin within regional geological map with rifts of West and Central African Rift System (after [10]). 
The stratigraphy of Bornu Basin has largely been interpreted by comparison with the Upper Benue Trough [7]. [7] also revealed that correlation of the Cretaceous succession in the Bornu Basin and Upper Benue Trough remains inexact. He pointed out that, [4] and [6] respectively suggested Albian to Turonian and Albian to Cenomanian ages for beds referred to the Bima Group in the Bornu Basin; Lower Turonian and Turonian ages for the Gongila Formation; and Turonian to Maastrichtian and Turonian to Santonian ages for Fika Shale. He further stated that although Okosun indicated the Kanadi well as bottoming in basement rocks, Olugbemiro reported only the Kinasar well as penetrating the full thickness of the Bima Group and "Pre Bima" beds.

The history of the Chad Basin according to [8], began before the beginning of Upper Cretaceous when continental sediments consisting of Bima sandstone were deposited unconformable on the Pre-Cambrian basement probably during Albian. The Gongila Formation mixed limestone/shale was deposited by marine transgression on the Bima sandstone in Early Cenomanian. Marine Fika shales of Cenomanian to Turonian age overlie these beds. Towards the end of the Cretaceous, an estuarine-deltaic environment prevailed and the Gombe sandstone was deposited with intercalations of siltstone, shales and ironstones. Based on NNPC well logs, the Gombe sandstone was observed to be limited in its aerial extent [9]. The Paleocene marked the period of deposition of the continental Kerri-Kerri Formation. The Chad Formation of Pliocene to Recent age overlies these sediments in the basin.

The most important formation as far as groundwater resources is concerned are the Chad and the Kerri-Kerri Formations. Fresh potable water $\left(1713 \mathrm{~km}^{3}\right.$ or $\left.15 \%\right)$ of all Nigerian fresh water is confined only to the uppermost part about $500 \mathrm{~m}$ of Chad Formation [11]. The whole of sedimentary fill of the Chad Basin estimated on basis of gravimetry at over 7000 metres with an exception to the Pindiga Formation is highly porous, moderately permeable and contains $9530 \mathrm{~km}^{3}$ of salty and fresh water, about $27 \%$ of all fresh and salty water in Nigeria [11] [12].

\section{Material and Method}

Two sources of geothermal information were gathered and utilizes in this research, these included shallow water wells and deep boreholes drilled for oil and gas exploration. Their parameters are presented in Table 1.

The data from 43 temperature measurement points were used for gradient calculations and map production, including 19 oil wells with BHT measurements corrected in this work and 24 water wells in which temperature was measured during pumping tests, collected for the previous work [12].

The values of geothermal gradient were calculated according to the formula:

Table 1. Temperature gradients used for production of geothermal gradient map of Nigerian sector of Chad Basin.

\begin{tabular}{|c|c|c|c|c|c|c|c|}
\hline $\begin{array}{l}\text { Name of } \\
\text { oil well }\end{array}$ & $\begin{array}{l}\text { Geothermal gradient } \\
{ }^{\circ} \mathrm{C} / 100 \mathrm{~m}\end{array}$ & $\begin{array}{l}\text { Name of } \\
\text { oil well }\end{array}$ & $\begin{array}{c}\text { Geothermal } \\
\text { gradient } \\
{ }^{\circ} \mathrm{C} / 100 \mathrm{~m}\end{array}$ & $\begin{array}{c}\text { Name of water } \\
\text { well }\end{array}$ & $\begin{array}{l}\text { Geothermal gradient } \\
{ }^{\circ} \mathrm{C} / 100 \mathrm{~m}\end{array}$ & $\begin{array}{c}\text { Name of water } \\
\text { well }\end{array}$ & $\begin{array}{l}\text { Geothermal gradient } \\
{ }^{\circ} \mathrm{C} / 100 \mathrm{~m}\end{array}$ \\
\hline $\mathrm{ABK}$ & 3.32 & MSU & 3.67 & $16 / 60 \mathrm{NL}$ & 2.81 & P267 & 4.08 \\
\hline BLT & 3.47 & MBJ & 3.07 & 27/527/KDG & 3.8 & 266/MA & 3.19 \\
\hline FLT & 3.01 & MRS & 2.99 & 26/281/JK & 4.22 & $27 / 513$ & 3.84 \\
\hline HRW & 3.09 & NGM & 4.29 & 23/BA & 2.85 & 15/321/Tb & 4.07 \\
\hline KND & 5.02 & SAA & 4.71 & $\mathrm{CH}-23$ & 3.15 & 15/222/BD & 5.84 \\
\hline KSD & 4.59 & TUM & 3.14 & $\mathrm{CH}-10$ & 2.84 & 15/224kum & 4.56 \\
\hline KMR & 5.88 & WAD & 3.74 & $\mathrm{CH}-11$ & 3.03 & 15/339AB & 4.56 \\
\hline KNS & 3.61 & WSH & 3.34 & 266/MA & 2.93 & 16/95/DL & 5.06 \\
\hline KRT & 3.08 & ZYE & 3.28 & $2 / 77-78$ & 3.52 & 14/294MG & 3.11 \\
\hline \multirow[t]{4}{*}{ KCL } & 3.24 & & & 245 & 3.98 & 28/142/GL & 4.45 \\
\hline & & & & 268/MA & 3.41 & 25/190FUN & 3.34 \\
\hline & & & & & & 18/158DBZ & 3.33 \\
\hline & & & & & & 26/315/GM & 2.94 \\
\hline
\end{tabular}




$$
G=(T d-T a) / h
$$

where

" $G$ ” is the geothermal gradient $\left({ }^{\circ} \mathrm{C} / \mathrm{m} ;{ }^{\circ} \mathrm{C} / 100 \mathrm{~m}\right)$,

" $\mathrm{Td}$ " is the natural temperature of rock formation at particular depth $\left({ }^{\circ} \mathrm{C}\right)$,

" $\mathrm{Ta}$ " is the mean annual air temperature at the ground level $\left({ }^{\circ} \mathrm{C}\right)$,

" $h$ " is the depth of the measurement (m).

Information on mean annual air temperature was read from the map by [13] (Figure 2).

The natural temperatures of rock formations at particular depths were calculated on the basis of BHT (Bottom Hole Temperature) measured in oil wells and corrected as well as on the basis of temperature measurements taken in the water wells during pumping tests, which is believed to be close to the natural temperature of the water bearing layer at some particular depth.

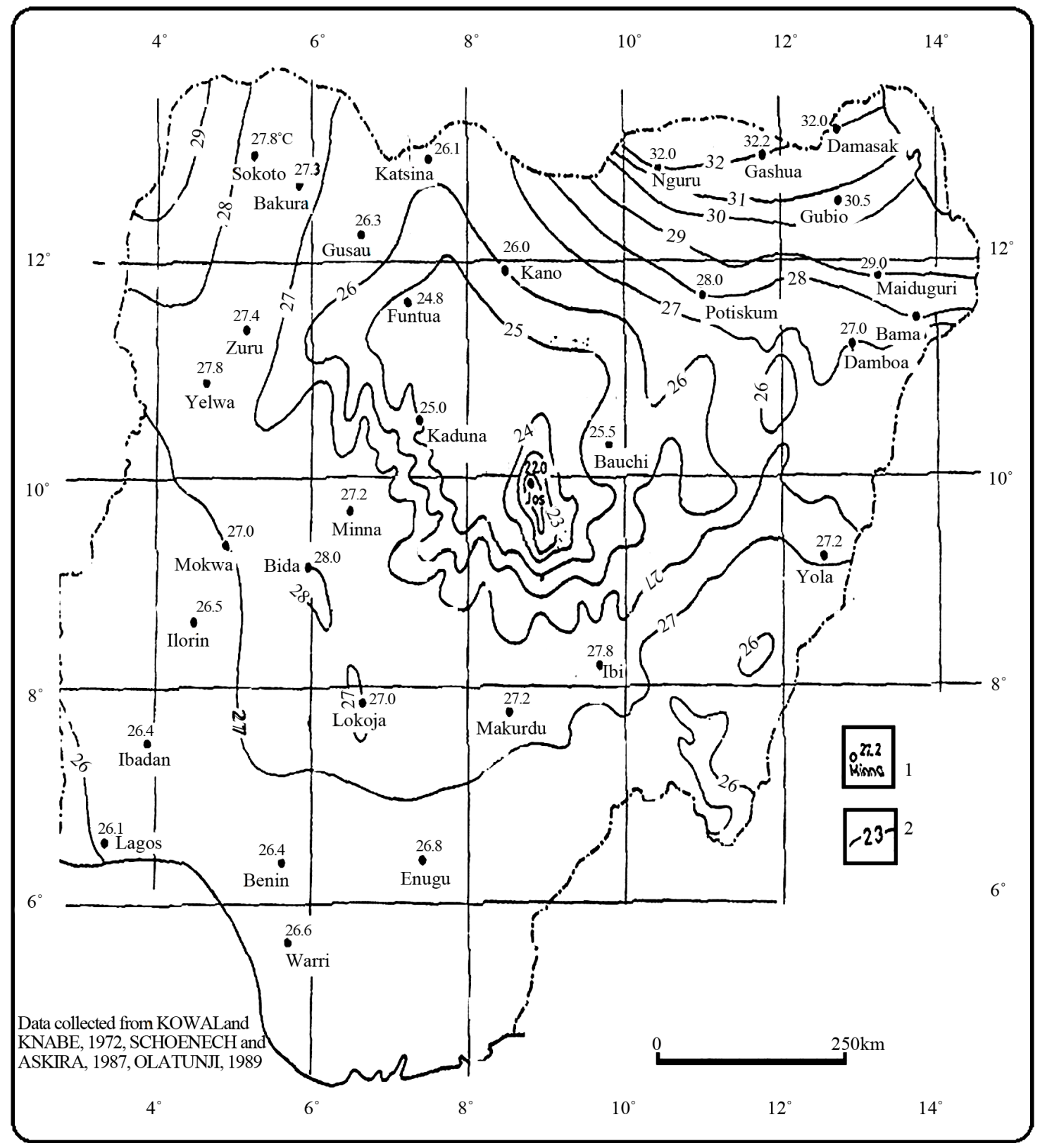

Figure 2. Map of annual ground surface temperature (after [13]). 
The data were inserted in Excell sheet together with the coordinates of each data point and then the data sheet was used in Surfer program for gridding and plotting the contours. Surfer, Global Mapper and MapInfo grid were utilized in preparing the final version of maps presented in this study.

The "Geothermal Gradient Map" presents the colors, contours and data points with values of temperature increase with depth expressed in ${ }^{\circ} \mathrm{C} / 100 \mathrm{~m}$.

The Heat Flow (HF) Map shows the distribution of the terrestrial heat flow within the research area detected on the ground surface and its intensity is presented in milli Watts per square meter unit $\left(\mathrm{mW} / \mathrm{m}^{2}\right)$. Therefore, the contours and colours show the value of geothermal heat flowing from the underground (from some depth) to the surface through a defined area. In this study the HF was calculated for each square meter $\left(\mathrm{m}^{2}\right)$ of the area.

The terrestrial heat flow is calculated according to the Fourier's law (which says that the heat flux resulting from thermal conduction is proportional to the magnitude of the temperature gradient) and is expressed by the equation:

$$
Q=-K \times G
$$

where

$Q$ is the heat flow $\mathrm{W} / \mathrm{m}^{2}$,

$K$ is the thermal conductivity of the rock formation $\mathrm{W} / \mathrm{m}^{\circ} \mathrm{C}$,

$G$ is the geothermal gradient ${ }^{\circ} \mathrm{C} / \mathrm{m}$,

"Minus" means that the heat is transferred from the higher towards lower temperature (from deeper part of the Earth to the surface) [14] [15].

In the Earth sciences the heat flow is calculated for the vertical column of some particular depth that can be represented by the lithological profile of the borehole for which the types of rock are known, so the thermal conductivity can be measured as well as the geothermal gradient. If several such data is available for some area, it is possible to plot the map since the heat flow values differ due to diversity of geological and hydrogeological conditions.

In this work the lithological and thermal data from 19 deep oil wells were used. The data set was supplemented with 24 point data on geothermal gradients from the water wells that were calculated in 2005, in the previous work [16]. The location of the data points is presented on the Heat Flow Map (Figure 5).

\section{Result and Discussion}

[17] utilized 12 oil wells and came up with geothermal gradient range between $2.16^{\circ} \mathrm{C} / 100 \mathrm{~m}$ and $5.26^{\circ} \mathrm{C} / 100 \mathrm{~m}$ in the Nigerian Chad Basin. Nwazeapu revealed that the geothermal gradient varies from well to well. According to Nwazeapu the wells that encountered intrusive rocks had an average geothermal gradient value of $3.73^{\circ} \mathrm{C} /$ $100 \mathrm{~m}$ while the wells that had no intrusive have an average value of $3.05^{\circ} \mathrm{C} / 100 \mathrm{~m}$.

[18] from corrected oil well temperatures also presented an average value geothermal gradient of $3.31^{\circ} \mathrm{C} / 100$ $\mathrm{m}$ in the Borno basin. Using corrected bottom hole temperature for some depth intervals of 3 wells [19] presented geothermal gradient range of $3.1^{\circ} \mathrm{C} / 100 \mathrm{~m}$ in Mbeji well to $4.2^{\circ} \mathrm{C} / 100 \mathrm{~m}$ in Albarka well, with an intermediate value of $3.9^{\circ} \mathrm{C} / 100 \mathrm{~m}$ in Kanadi well.

[16] Presented a geothermal gradient range of $1.35^{\circ} \mathrm{C} / 100 \mathrm{~m}$ to $5.80^{\circ} \mathrm{C} / 100 \mathrm{~m}$ in the Chad Basin of Nigeria based on temperature information from more than 100 boreholes. [13] published a modified and improved version of geothermal maps where three different geothermal anomalies (Gashua, Jakana \& Bida Walasa) where presented (Figure 3).

[20] titled "Estimation of the heat flow variation in the Chad Basin Nigeria" using wire line logs from 14 oil wells, came up with the geothermal gradient average of $3.4^{\circ} \mathrm{C} / 100$ and a regional range of $3.0^{\circ} \mathrm{C} / 100 \mathrm{~m}$ to $4.4^{\circ} \mathrm{C} / 100 \mathrm{~m}$ [20] further obtained the thermal conductivity variation from 1.70 to $3.11 \mathrm{~W} / \mathrm{m}^{\circ} \mathrm{C}$ with an average value of $2.35 \mathrm{~W} / \mathrm{m}^{\circ} \mathrm{C}$ and mean heat flow values vary from 63.6 to $105 \mathrm{~mW} / \mathrm{m}^{2}$ with a simple average of 80.6 $\mathrm{mW} / \mathrm{m}^{2}$.

[21] analyzed bottom hole temperature (BHT) data from 21 one wells in the Nigerian sector of the Chad Basin and obtained a regional average geothermal gradient of $3.4^{\circ} \mathrm{C} / 100 \mathrm{~m}$.

The geothermal gradient from the 19 oil exploration wells ranged from $2.99^{\circ} \mathrm{C} / 100 \mathrm{~m}$ to $5.88^{\circ} \mathrm{C} / 100 \mathrm{~m}$ with an average of $3.84^{\circ} \mathrm{C} / 100 \mathrm{~m}$. The geothermal gradients calculated from the 24 water boreholes obtained indicate a range of $2.81^{\circ} \mathrm{C} / 100 \mathrm{~m}$ to $5.84^{\circ} \mathrm{C} / 100 \mathrm{~m}$ with average of $3.71^{\circ} \mathrm{C} / 100 \mathrm{~m}$ (Table 1). Combination of the geothermal data from the two sources, oil and water boreholes together produced a geothermal gradient range of 




Figure 3. Geothermal cross-section in Borno Basin (after [16]).

\section{$2.81^{\circ} \mathrm{C} / 100 \mathrm{~m}$ to $5.88^{\circ} \mathrm{C} / 100 \mathrm{~m}$ with an average of $3.71^{\circ} \mathrm{C} / 100 \mathrm{~m}$.}

Geothermal gradient of both the oil exploration wells and water boreholes were merged and used to construct the geothermal gradient map of the Nigerian sector of the Chad Basin (Figure 4).

According to the map, geothermal gradient of $4^{\circ} \mathrm{C} / 100$ was recorded in areas of Gulumba, Kukawa and Dikwa, the highest value of $5.84^{\circ} \mathrm{C} / 100$ was obtained south of Bida and lower values of $2.85^{\circ} \mathrm{C} / 100$ and $2.80^{\circ} \mathrm{C}$ $/ 100$ was around Bama and Kala Balge, respectively.

Geothermal gradient is a good indicator of sub-surface temperature distribution and in the assessment of geothermal energy resources of an area. In the present study, the geothermal gradient in the Borno Basin varies from $2.81^{\circ} \mathrm{C} / 100 \mathrm{~m}$ to $5.88^{\circ} \mathrm{C} / 100 \mathrm{~m}$ with an average of $3.708^{\circ} \mathrm{C} / 100 \mathrm{~m}$. Different but close values were reported by different authors from previous work. [17] reported $2.16^{\circ} \mathrm{C} / 100 \mathrm{~m}$ to $5.26^{\circ} \mathrm{C} / 100 \mathrm{~m}$, Kwaya (2005) obtained values ranging from $1.35^{\circ} \mathrm{C} / 100 \mathrm{~m}$ to $5.80^{\circ} \mathrm{C} / 100 \mathrm{~m}$, [20] and [21] presented a regional geothermal gradient of $3.4^{\circ} \mathrm{C} / 100 \mathrm{~m}$. In a far away Chadian sector of the Basin, [22] produced a range of $1.6929^{\circ} \mathrm{C} / 100 \mathrm{~m}$ to $8.3817^{\circ} \mathrm{C} /$ $100 \mathrm{~m}$. Assessment of the present and previous values reported on the geothermal gradient shows that the geothermal background of the Nigerian sector of the Chad Basin remains more than $3^{\circ} \mathrm{C} / 100 \mathrm{~m}$. This is adequate for attainment of profitable geothermal energy resource in a deep sedimentary basin like the Nigerian sector of the Chad Basin, especially in the areas of positive thermal anomalies where the geothermal gradient is about $5^{\circ} \mathrm{C}$ / $100 \mathrm{~m}$.

[23], commenting on the SE-NW trend of the anomalies, suggested correlation with structural features of the Basin: Warm anomalies indicate grabens, while cool anomalies horsts in the crystalline bottom of the Basin

Heat flow determination in a region provides significant tool for clarifying the ongoing thermal activity within the area. The present work presented a heat flow (Figure 5) value ranging from $45 \mathrm{~mW} / \mathrm{m}^{2}$ to about $90 \mathrm{~mW} / \mathrm{m}^{2}$ in the Nigerian sector of the Chad Basin. [20] working on the "Estimation of the Heat flow variation in the Chad Basin Nigeria" came up with a value varying from $63.6 \mathrm{~mW} / \mathrm{m}^{2}$ to $105.6 \mathrm{~mW} / \mathrm{m}^{2}$ with average of $80.6 \mathrm{~mW} / \mathrm{m}^{2}$, and concluded that there was no distinct trend on heat flow within the Basin.

\section{Conclusions}

Geothermal gradient which is the rate of temperature increase with depth is a good indicator of sub-surface 


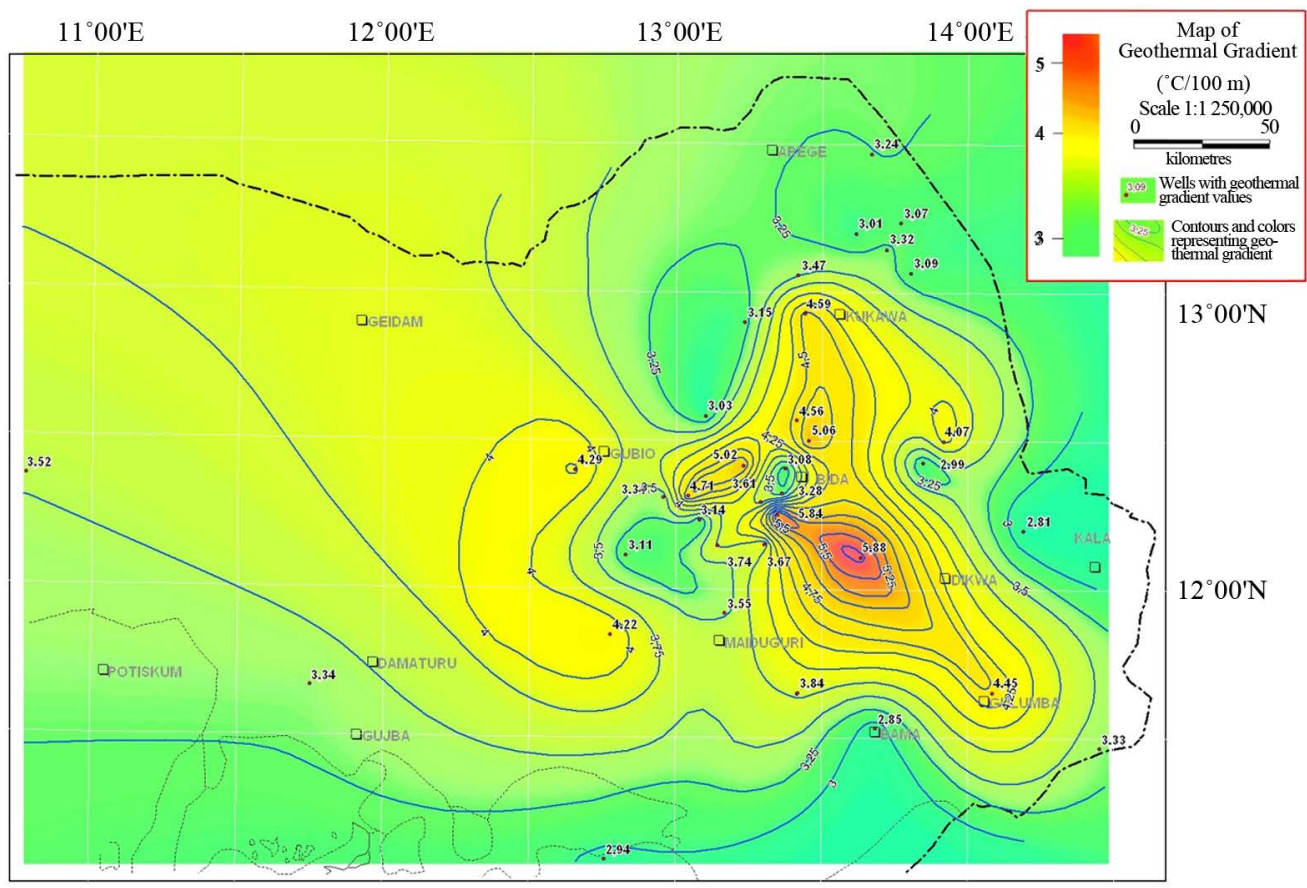

Figure 4. Geothermal gradient map of the Nigerian sector of the Chad Basin.

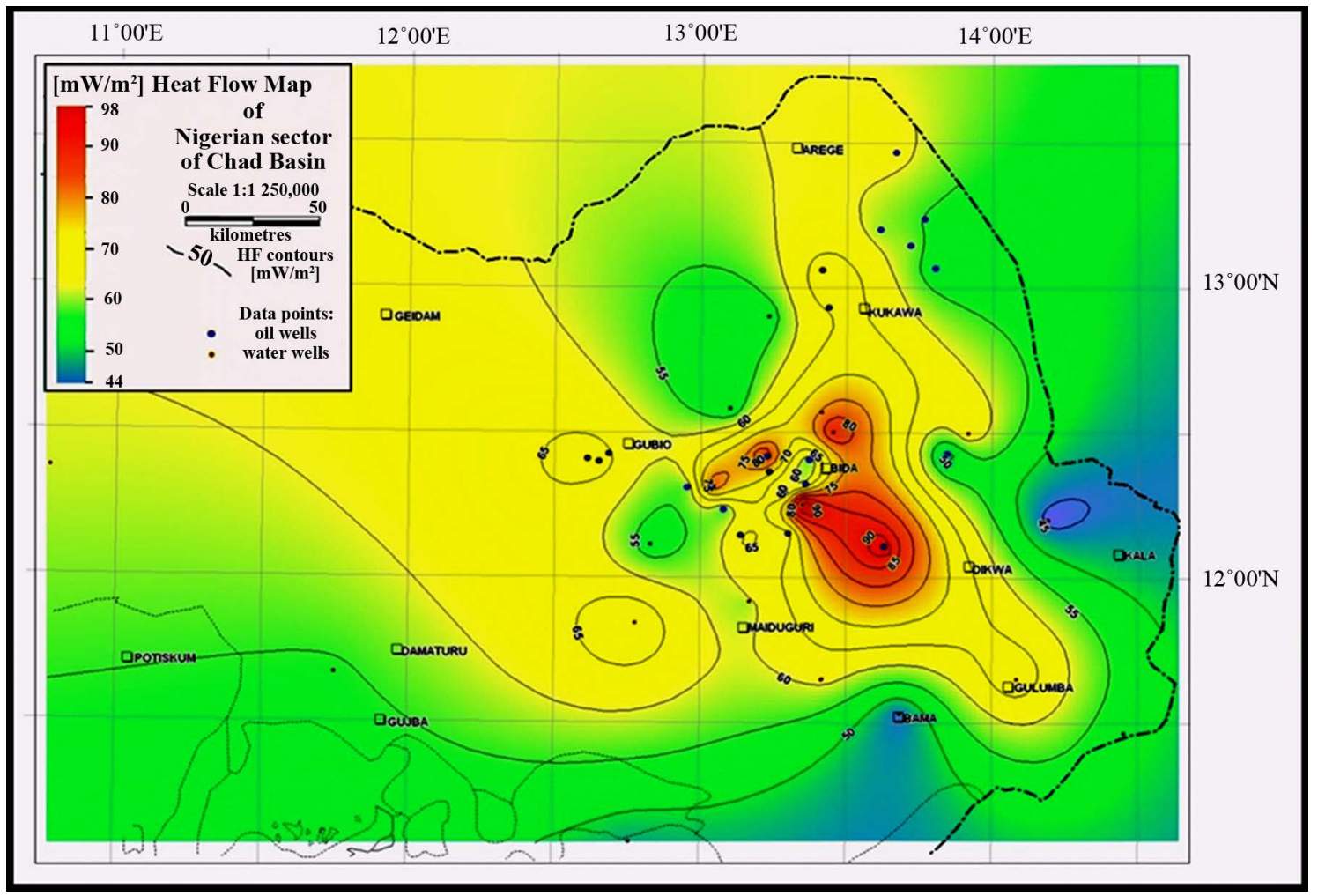

Figure 5. Heat flow map of Nigeria sector of the Chad Basin.

temperature distribution and in the assessment of geothermal energy resources of an area. In the present study, the geothermal gradient in the Borno Basin varies from $2.81^{\circ} \mathrm{C} / 100 \mathrm{~m}$ to $5.88^{\circ} \mathrm{C} / 100 \mathrm{~m}$ with an average of $3.708^{\circ} \mathrm{C} / 100 \mathrm{~m}$. 
Assessment of the present and previous values reported on the geothermal gradient shows that the geothermal background of the Nigerian sector of the Chad Basin remains more than $3^{\circ} \mathrm{C} / 100 \mathrm{~m}$. This is adequate for attainment of profitable geothermal energy resource in a deep sedimentary basin like the Nigerian sector of the Chad Basin, especially in the areas of positive thermal anomalies, where the geothermal gradient is about $5^{\circ} \mathrm{C} / 100 \mathrm{~m}$.

Heat flow determination in a region provides significant tool for clarifying the ongoing thermal activity within the area. The present work presented a heat flow value ranging from $45 \mathrm{~mW} / \mathrm{m}^{2}$ to about $90 \mathrm{~mW} / \mathrm{m}^{2}$ in the Nigerian sector of the Chad Basin.

\section{Acknowledgements}

The authors are very grateful to all staffs of the Department of Fundamental Geology, University of Silesia in Katowice, Poland, especially Dr. M. Zbigniew and Prof. Jarzy Jaba. Also deserving our appreciation are the staff of Polish Geological Institute Warsaw for their support during the laboratory work, and NAPIMS NNPC Nigeria for the release of some oil well data, Tertiary Education trust fund (TETFUND) Nigeria, UNESCO Poland, University of Silesia (US)-Ahamdu Bello University (ABU), Zaria research linkage program for their support.

\section{References}

[1] Binks, R.M. and Fairhead, J.D. (1992) A Plate Tectonic Setting for Mesozoic Rifts of West and Central Africa. Tectonophysics, 213, 141-151. http://dx.doi.org/10.1016/0040-1951(92)90255-5

[2] Dickson, M.H. and Fanelli, M. (2004) What Is Geothermal Energy? International Geothermal Association, Bochum.

[3] Oteze, G.E. and Fayose, S.A. (1988) Regional Development in the Hydrogeology of Chad Basin. Water Resources Journal, 1, 9-29.

[4] Okosun, E.A. (1995) Review of the Geology of Borno Basin. Journal Mining and Geology, 21, 113-122.

[5] Cratchley, C.R., Louis P. and Ajakaiye, D.E. (1984) Geophysical and Geological Evidence for the Benue-Chad Basin Cretaceous Rift System and Its Tectonic Implications. Journal African Earth Sciences, 2, 141-150. http://dx.doi.org/10.1016/s0731-7247(84)80008-7

[6] Olugbemiro, O.R. (1997) Hydrocarbon Potential, Maturation and Paleoenvironment of the Cretaceous, CinomanianSantonian. Series in the Borno, Chad Basin, NE Nigeria. Tiibinger Mikropalaontologische Mitteilungen, 14, Viii + 150 p.

[7] Zarborski, P.M. (1998) A Review of the Cretaceous System in Nigeria. African Geosciences Review, 5, 385-483.

[8] Barber, W. (1965) Pressure Water in the Chad Formation of Borno and Dikwa Emirate, Northeastern Nigeria. Nigeria Geological Survey Bulletin \# 35, 138 p.

[9] Bako, M.D., Adetola, B.A. and Umaru, A.F.M. (1998) The Chad Basin Aquifers; New Evidence from Seismic Reflection Section and Wire-Line Logs. Water Resources Journal, 9, 10-21.

[10] Genik, G.J. (1992) Regional Framework, Structural and Petroleum Aspects of Rift Basins in Niger, Chad and Central African Republic (C.A.R.). Technophysics, 213, 169-185. http://dx.doi.org/10.1016/0040-1951(92)90257-7

[11] Schoeneich, K. (2005) Budget for Basin Development Authority, Full Version. Nigerian Mining and Geosciences Society, 4th International Conferences, Maiduguri.

[12] Kwaya, M.Y., Schoeneich, K. and Ikpokonte, A.E. (2005) Thermal Water in Borno Basin. Borno Journal of Geology, 3, 5 .

[13] Schoeneich, K. (1998) Unpublished Lecture Notes on Hydrogeology. Department of Geology, Faculty of Science. Ahmadu Bello University, Zaria.

[14] Okosun, E.A. (1992) Cretaceous Ostracod Biostratigraphy from Chad Basin in Nigeria. Journal of Africa Earth Sciences, 14, 327-339. http://dx.doi.org/10.1016/0899-5362(92)90036-C

[15] Chilingar, G.V., Edwards, L., Fertl, W. and Rieke, H.H. (1982) Handbook of Geothermal Energy. Gulf Publishing Company, Houston.

[16] Schön, J.H. (2011) Physical Properties of Rocks, Vol. 8: A Workbook (Handbook of Petroleum Exploration and Production). Elsevier, Netherlands, 337-361.

[17] Kwaya, M.Y. (2005) Thermal Groundwater in Borno and Yobe States, Nigeria. Unpublished Masters of Science thesis, Department of Geology Ahmadu Bello University, Zaria.

[18] Nwazeapu, A.U. (1990) Hydrocarbon Exploration in Frontier Basin: The Nigerian Chad Basin Experience. Presented at 28th Annual Conference of the Nigeria Mining and Geosciences Society, Port Harcourt, p. 14. 
[19] Umar, T. (1999) Geologie Petroliere du Secteur Nigeria du Lac Tchad. Unpublished PhD Dissertation, Universite du pau et des pays de l'adour, Centre Universitaire de Recherche Scientifique Laboratoire de Geodynamique et Modelisation des Bassins Sedimentaires, 425 p.

[20] Nwankwo, C.N., Ekine, A.S. and Nwosu, L.I. (2009) Estimation of the Heat Flow in the Chad Basin Nigeria. Journal of Applied Sciences and Environmental Management, 13, 73-80.

[21] Nwankwo, C.N. and Ekine, A.S. (2009) Geothermal Gradient in the Chad Basin, Nigeria, from Bottom Hole Temperature Logs. International Journal of Physical Sciences, 4, 777-783.

[22] Roland, G. and Doumnang, J. (2012) Geothermal Exploration in Surrounding Area of N'Djamena Region. Journal of Basic Applied Scientific Research, 2, 4733-4739.

[23] Askira, M.T. and Schoeneich K. (1987) Thermal Maturity and Hydrocarbon Potential of the Cretaceous (CenomanianSantonian) Sediments in the Bornu (Chad) Basin, NE Nigeria. Bulletin de la Societe Geologique de France, 170, 759772. 